\title{
Area Studies and Study Abroad: The Chinese Experience
}

\author{
Gregory K u l a cki
}

Pitzer College

\section{Introduction}

Several years ago I arranged to have a representative of the foreign press corps speak at a student dinner. The group of twenty American undergraduates was well into a semester of language and cultural studies at Beijing University and beginning to feel comfortable with the language and the lay of the land. The journalist was a graduate of the same study abroad program and a very charismatic speaker. His pedagogical aim for the evening was to help his aspiring successors understand the professional life of American expatriates in the People's Republic and their role in shaping policy and public opinion in the United States. After regaling the group with heroic tales of Tiananmen in ' 89 , he closed with a curious comment that went straight over the heads of the brightest products of America's best colleges and universities:

After my first semester here as a foreign student I thought I could write a book on China. At the end of the first year I still felt I could write a decent article. Now, after more than five years in this country, I could write everything I know about China on the back of a matchbook cover.

This kind of intellectual modesty is unusual in a journalist and extremely rare among American reporters in Beijing. The recommended reading lists for most of the major U.S.-based study abroad programs in China contain more than a few titles by American journalists who felt compelled to write books about the Middle Kingdom. Together with their counterparts in academia, the so-called "China hands" have assembled an impressive storehouse of expertise that over the last fifty years has 
coalesced into an institutionalized body of knowledge. What is the relationship between that body of knowledge and the study abroad experience? While there are no easy answers, I believe the sentiments expressed by our speaker are an indication that study abroad can have a powerfully positive impact on the future of area studies. Properly conceived and implemented as an integral part of the Chinese studies curriculum, study abroad has the potential to transform what has often been a theoretically and morally questionable enterprise into a more comprehensive and balanced attempt to understand the subject of its inquiry.

Lack of balance in the area studies literature on China is a natural and understandable outcome of the unbalanced relationship between China and those who have made it an object of study. As much as some of us involved in cross-cultural education might like to think otherwise, patterns of cross-cultural interaction do not emerge in isolation from the social, political, and economic activity that actually brings people together. The content of any cross-cultural discourse is guided by the questions and concerns of the individuals and institutions engaged in cross-cultural pursuits. As a field of inquiry, Chinese studies has never existed in an abstract, value-free intellectual domain that does not intersect with actual events. Area experts have advised civil, military, and government actors, received funding from vested economic and political interests, and personally intervened in diplomatic, commercial, and public affairs. The discipline has a well-established world view that, while not consciously embraced by many scholars in the field, has nevertheless exerted considerable influence over the course of the cross-cultural relationship between China and the West.

Educational exchange has played a fundamental role in the evolution of that relationship. Questions about cultural differences have been at the core of a violent process of political, economic and social change that, on both sides of the cultural divide, defines progress as a movement away from generally negative Chinese traditions towards a generally positive and supposedly universal modernity that is actually Western in origin. The principle vehicle of change has been the "Westernization" or "reform" of the education of Chinese youth. From the "New Culture Movement" of the early 1900s, through the "Cultural Revolution" of the sixties and seventies, to the student demonstrations in Tiananmen Square in 1989, the history of twentieth-century China has been punctuated by political 
movements led by young men and women using Western symbols, images, and values to challenge an established authority believed to be holding China back because of their inability to sever behavior from traditional "Confucian" or "feudal" values.

Students who have confronted these events through area studies courses are influenced according to their individual orientation to the necessarily small subset of the content they have assimilated. There is considerable variation in the academic literature and even greater variation in both its presentation and the way it is received by individual students. They could wholeheartedly agree with an admired professor or passionately reject ideas presented by teachers who did not earn their respect. Students from Chinese-American households may react differently to area studies course content than students who do not have an intimate and longstanding exposure to Chinese culture. Vegetarians with an emotional investment in the Dalai Lama may approach questions from a different point of view than economics majors with a professional investment in access to the Chinese market. While individual cross-cultural encounters are, theoretically, idiosyncratic and free to evolve in many directions, over the period of ten years I spent shepherding American undergraduates through study abroad programs in China, I was able to observe relatively consistent patterns of intercultural behavior that appeared related to a student's prior knowledge of China.

Lectures and readings on cross-cultural communication designed to increase a student's capacity to suspend cultural judgments were a standard part of preparation for study in China. Students with a background in East Asian studies, Chinese studies, international relations, comparative politics, or other academic disciplines that brought them into contact with area studies expertise on China were markedly less receptive to this part of the orientation program. Over the course of the semester they were, not surprisingly, less willing or able to put aside cultural prejudices. In comparison with students majoring in English, the fine arts, or academic disciplines where there was little or no contact with area studies content, "informed" students were far less able to tolerate ambiguity. Prior knowledge had armed them with ready resolutions of the adjustment problems inherent in many of the cross-cultural encounters that occur during a student's first semester in China. A disproportionate number of these resolutions were grounded on ideological interpretations of behavior 
rather than on interpretations based on the gender, social class, religious convictions, age, personality or interests of the Chinese individuals they engaged. Comprehensive structural explanations of events were more common than explanations grounded in the specific circumstances of a given situation. A store clerk's failure to provide prompt service would be interpreted as "xenophobia" or the result of "the lack of incentives in a socialist economy," rather than the clerk's work ethic, state of mind, or patience with idiomatically-confusing and poorly-pronounced Chinese. A slowdown in the flow of letters from home would be perceived as "government inspection of my mail" rather than the retreating interest of family and friends or the sudden illness of a key member of the university mailroom staff. The aggressive attentiveness of a new Chinese friend who mentioned she was a member of the Chinese Communist Youth League would be characterized as "spying" rather than a consequence of an unmentioned interest in Christianity, a personality quirk, or confusion about how to show friendship to an American. English majors with no prior training in Chinese studies but some familiarity with contemporary press reports might have similar thoughts, and be prone to similar resolutions, but they would usually come to me to ask about an ambiguous or confusing event or encounter. East Asian studies majors generally would not bother asking, would lead their classmates to interpret incidents in a similar way, and would nurture these kinds of suspicions for an entire semester before exploding in some kind of rage that would then bring their thoughts and feelings to my attention. Of course these incidents are anecdotal, and did not apply in every instance to students with or without prior area studies training. Nevertheless, twenty semesters of similar anecdotes are fairly persuasive, and my experience in China in this role has led me to question the nature of Chinese studies, to wonder about the efficacy of area studies prerequisites for study abroad, and to pay closer attention to pre-departure reading lists.

\section{Area Studies Paradigms of the Chinese Experience: Classicist, Maoist and Modernist}

J.L. Metha, in a lecture summing up a lifetime of effort to develop a dialogue between the Indian tradition in which he was raised and the Western letters for which he held a personal fascination, observed that: 
A certain degree of alienation, opacity, and bafflement, a sense of resistant otherness, prompts the effort to understand, and this has therefore always an other for its object, be it the otherness into which parts or elements of my own tradition have lapsed, be it the ways of living and thinking belonging to alien religious and cultural traditions.(1989: 2)

The Indian phenomenologist identified an aspect of the effort to achieve cross-cultural understanding that also characterizes the Western student's or scholar's relationship to China. It is the fascination with something other, the attraction to an appealing entity outside the conceptual boundaries of his or her individual sense of self. Charles Hucker, an accomplished student of Chinese history, captured the essence of this infatuation when he described China as "a highly complex civilization rooted in conditions and attitudes different from those in which Western civilization developed, so that it can serve us as a kind of distorting mirror in which, by seeing what we are not, we might understand ourselves more maturely" (1978: 4). Herrlee Creel, author of a number of seminal works on Chinese thought, put it somewhat differently, suggesting that we can "view China as a great social laboratory in which for three thousand years of recorded history men and women have been doing things with ideas and institutions that are often quite different from the things we do" (1953: 8). Like Hucker, he argued that the "greatest use that a knowledge of China can have for us in the West is that it will set our own problems in a new light and let us look at them more objectively." Most of the social scientific research on China contains some reference to what the Asia Society once called "The China Difference" (Terrill 1979), or what Francis Hsu (1972) described as the "differing mental universes" of Chinese and Western people. These kinds of sentiments are also standard fare in student application essays for study abroad programs. China is often characterized as the very opposite of all that is "us." It is the quintessential Western "them."

For many Western students and scholars, contact with China is a foray into the irrational and the aesthetic, into what Georges Bataille called "the heterogeneous"; a realm that resists integration with the Weberian rationalism that dominates the consciousness of the modern West. Joseph Needham opened one of his later works on China with a discussion of how his wartime assignment in Chongqing "sealed his fate," 
and how after living in China it was "impossible to think of doing anything else but a book on the history of science, technology, and medicine in China" (1954: 149). This followed an initial attraction to the Chinese language that he described as being "struck down by a blinding light, like Saint Paul on the way to Damascus, with the feeling that I must learn this language with its marvelous script or else burst." Needham surrendered a promising career in biochemistry to his emotional encounter with China, to an aesthetic that was charged with an eroticism Bataille would have expected. According to fellow Sinologist Simon Leys (1985), Needham once told him that "Chinese civilization presents the irresistible fascination of what is totally other, and only what is totally other can inspire the deepest love, together with a strong desire to know it." 1

Expressions of love and desire for China appear frequently in the ruminations of Western scholars interested in the Chinese past, but they are noticeably absent in the social scientific literature on modern China. Needham self-consciously concludes his studies at precisely the same historical moment that Jonathan Spence (1990) begins his Search for Modern China: the arrival of Jesuit missionaries during the late Ming Dynasty. Hucker ends his introduction to Chinese history and culture in 1850, the year that he believes "marks the end of traditional or pre-modern Chinese civilization." Creel stands in the doorway of modern China, surveys the intellectual terrain, and then retreats into what he sees as the "contentment" of traditional Chinese political philosophy. He scorns the "speedway of modern living," the "saber-rattling," and the "aggressive and competitive" tendencies of modern life, whose "wreckage has to be patched up in the psychiatrist's office." Leys, who once said he loved China more than his own country, summed up the disposition of the classicist toward contemporary China:

"Why the interest in contemporary China?" I was asked by one of my
elders in Sinology, a scholar who I like and respect. I confess that his
question astounded me. Is there a Sinologist alive who does not feel in
exile when he is away from China? Another one, a dear friend, said
to me, "Your book Leys Habits neufs du President Mao was a
pretty piece, but I hope you'll waste no more time with Chinese affairs.
Leave that to the journalists, and come back to your work on the clas-
sics." (1985: 1)


While Leys and many others with a passion for China's past feel compelled to ignore such advice, they look upon contemporary Chinese culture as a "burning forest" and see themselves, as Leys sees himself and his idols, as a "flock of wild doves" trying in vain to save their beloved China with drops of water carried on the tips of their tired wings. Such a powerful identification sets classicists up as critics of a destructive present that defines for them the very otherness that attracts them to China. In conceiving China as the antithesis of the West, their life's work becomes a mission to save China from disintegration into the modernity that defines their own culture. So it is that the love and attraction many Western scholars hold for the Chinese past sometimes engenders feelings of bitterness toward contemporary China.

For those who lack the classicist's longing for return, for students and scholars who welcome modernity and do not seek to escape it with a retreat into antiquity, this bitterness is sometimes diluted into a nostalgic regret over what needs to be sacrificed if China is to finally become part of their inevitable, scientific, technological, predictable, and rational world. This nostalgia must not impede the social scientific enterprise. Lucian Pye, a prolific author and the godfather of comparative political and psychological investigations of Chinese culture, once lamented that:

once one turns to the bistory of old China one is quickly swept into a marvelous and fascinating world, which is so intrinsically interesting and exciting that the current China is drab and insignificant by comparison. This tendency has been substantiated time and time again in recent years in the careers of young scholars who set out to study what they believe to be the excitement of Communist China only to be seduced by the alluring appeals of earlier times. (1968: vi)

Pye (1991) wants to "help" the Chinese outgrow what he calls the "irrational" and "bizarre" traditional political culture he believes is frustrating Chinese efforts to join the modern world. He seems unabashedly annoyed by the romanticism of scholars like Needham and Creel. In his view it distracts budding analysts from their responsibility to resolve the pressing political crisis emerging from "the clash between individual political cultures and the world culture of modernization" (Pye, 1990).

China experts, nourished on the sense of crisis and specially trained to cope with a communist China during the postwar American China- 
studies boom, rely on this fear to sustain their interest in the pursuit of specialized knowledge about contemporary China. For Bataille, fear, like love, is an expression of the forces of "affective life" that break through and split off into the heterogeneous those elements, like China's "bizarre" culture, which threaten the steady continuation of modern rationalism's power over human life. The social scientific specialist in Chinese culture shares the classicist's attraction to China as other. But because their attraction is born from fear, they seek to liberate the Chinese people, and the world, from the dangers the persistence of China's "erratic" culture (Pye 1991) creates for the culture of modernization. In the introduction to his Anatomy of China, Dick Wilson expressed both the fear of contemporary China and the social scientific will to tame it by intellectually dissecting it. He believed scholars could employ their knowledge to force China, that most resistant other, to live within the confines of Western rationality's control:

The outside world is awed and frightened by the spectacle of a country that contains a quarter of mankind flexing her muscles for the first time in centuries - yet language, culture, religion, history, and political ideology combine to insure that Americans and Europeans misunderstand China more profoundly than they do any other part of the non-Western world. Indians and Japanese, Africans and Arabs are all now to some extent incorporated within a Europe-initiated world system. Only China resists, but the forces of the contemporary Chinese revolution can be made to yield to analysis and comprehension in Western terms, and that is what this book attempts. (1968)

Although written in the 1960 s, Wilson's remark would not be out of place today on the floor of the U.S. Congress as it debates funding for cultural exchange with China or in a corporate-sponsored roundtable for U.S. entrepreneurs in Beijing. The American public's fear of China, according to a recent Luce Foundation survey (Watts 1999), has trebled during the last two decades, despite what they call "the historical American fascination with the world's most populous nation." The Chinese studies community must bear some responsibility for the creation of this fear, which one would have expected to dissipate given the increased numbers of Americans interacting with China and the waning of the ideological battles waged as part of the Cold War. 
Love and fear continually recreate two distinct sets of attitudes toward China in the West that are the product of two academic dispositions reflecting shifts in focus from past to present. As a whole they allow China a grand and equal place in the human past where its culture becomes another great, exotic, alluring avenue into an alternative world. These feelings of appreciation and respect for the Chinese past give foreign students of Chinese culture the illusion they have overcome the possibility of harboring any ethnocentric bias, and that they have somehow merged with this ultimate other. These feelings often dissipate rapidly when foreign students and scholars interact with real Chinese people and functioning Chinese institutions during their stay abroad. It does not follow that respect for Chinese culture as a tradition assures respect for it as a living culture in the modern era.

Indeed, many social scientists see contemporary China as a problem to be solved. Studies of Chinese political life try to predict foreign policy, outbreaks of social unrest or future coalitions of political leaders. Essays on contemporary culture either lament its destruction or express the vain hope that it might be improving under "liberal" reforms. Economists ponder access barriers to the Chinese market or the potential power of a rapidly developing economy. Lawyers lament Chinese disregard for international contract law or violations of human rights. At critical moments, some area studies scholars go beyond inquiry to advocacy and intervention. After the violence in Tiananmen Square in 1989, Lucian Pye, then President of the American Political Science Association, used his presidential address to plead with his colleagues to make a concerted effort to train young Chinese intellectuals to overcome the particularistic, nationalistic, and traditional cultural concepts that form obstacles to their ability to embrace the "architectonic world structures" of the "culture of modernization." Invoking the legacy of Max Weber, he argued for a return to practicing "politics as a vocation" (1990: 16). These missionary impulses and paternalistic habits of mind are occasionally present in American students in China, who sometimes imagine they are going to introduce Chinese friends to facts, thoughts and behaviors that they have been denied by the authoritarian monsters that have supposedly brainwashed them since birth. One of the wonders of study abroad is how quickly that sort of arrogance disappears when real friendships are formed. Unfortunately, despite nearly two decades of expanding educational 
exchange with the mainland, American studies of contemporary China remained focused on reforms, progress, and development-that is, on signs that their subject is joining the modern world that informs the social scientific interest in China.

Paradoxically, these very studies are sustained by China's undying heterogeneity, which is in turn attributed to the preservation of traditional Chinese culture. John Fairbank, a preeminent scholar who dominated social scientific Sinology while he was alive and whose students now teach many of the young men and women applying to study abroad in China, clearly expresses this theoretical Catch-22 in the opening pages of his final work on the history of modern China (Fairbank 1987). The patriarch wrote, as he often did, of a cultural difference that "handicaps" the Middle Kingdom. Once made aware of their debilitating otherness, Chinese "suddenly found themselves left behind" foreign peoples they had previously considered inferior. Ever since they came to this sobering realization, the Chinese have been struggling desperately to catch up to an enlightened West. It is an especially difficult struggle because the Chinese have been "obliged to modernize from within their own cultural tradition, which resists change." Thus, for Fairbank, and the many who share his views, the strength and longevity of Chinese culture has become the greatest impediment to China's admission to what he described as the "emerging international culture of science and technology." More explicitly, "China has had farther to go and more changes to make than most countries simply because it has been itself for so long." Although his work is filled with protestations of respect and appreciation for Chinese culture, the clear and inescapable conclusion of Fairbank's analysis is that the Chinese, if they are to join the modern world, must cease to be themselves. So long as China remains Chinese, so long as it retains a heterogeneous quality, there will never be an end to the Western search for modern China.

There were a group of scholars during the Maoist period who were not drawn to China by a romantic interest in the Chinese past or a fear of its stubborn refusal to yield to cultural modernization. They found in China a different kind of heterogeneity and were willing to recognize a revolutionary break with the Chinese past their social scientific adversaries would not see. Mao Zedong's appeal to Western supporters of the Chinese communist revolution was unmistakably associated with the alternative he promised to both bourgeoisie liberalism and Soviet Marxism. The charis- 
matic peasant leader of a fifth of the human race embodied their hopes for a more humane "third world." William Hinton, one of the more influential Western advocates of the Maoist vision, wrote that

working class power had already been subverted in Russia and most of Eastern Europe and (...) was under serious challenge everywhere else. At this critical juncture the Chinese working class and its Communist Party went on the offensive. (...) Without any beaten path to follow, without any tested theory to light their way, China's revolutionaries now stood at the cutting edge of history. Whether or not they are able to consolidate power and carry the socialist revolution forward where others have failed is of crucial importance not only to the Chinese people, but to the anti-imperialist struggle of all the oppressed peoples and to the revolutionary struggle of the exploited classes. Whoever doubts this should try to imagine the world without a powerful socialist state to confront and expose both imperialism and social imperialism, to give aid to national liberation struggles, to pioneer in building a new society free from exploitation and oppression. (1970: 10)

These scholars share with the classicists an aesthetic emotional attachment to China as an other of modernity. But instead of investing their energies and interests in communication with alternative modes of life buried in the Chinese past, Hinton and those sympathetic to his view saw revolutionary China standing on the cutting edge of the present, opening a way to a better future for all humanity. Mark Selden saw the Chinese revolution as a chance to "break the shackles of oppression, poverty, and fear," and to "translate their hopes and dreams into dynamic action to expand human freedom and possibility" (1971: vii). Chinese revolutionaries proved to the alienated human community that people could realize "a vision of man and society and an approach to development built on the foundations of popular participation and egalitarian values." It was a revelation that offered inspiration "not only to those who would expel colonial oppressors, but to men and women everywhere who seek to create a society free from stifling oppression, arbitrary state power, and enslaving technology." One finds in a variety of books published in the West during the Maoist period declarations like: "Of the great leaders of the world, only Mao is a poet." Such statements accentuate the anti-tech- 
nical, anti-bureaucratic ethos of a revolution directed by the "only" world leader who in addition to "writing dry tracts on ideology and politics" was also "capable of writing with great feeling and sensitivity about human matters" (1967: 109).

Mao forged a clear and important link between the romantic and the revolutionary wings of the Chinese studies community. The Chinese leader appeared to many disillusioned Western youth as a traditional poet, bringing the force of an ancient humanist philosophical legacy to bear in a world-historical revolution against a techno-bureaucratic establishment that alienated and oppressed idealistic human beings from Berkeley to Paris to Peking. In the United States and Europe the aesthetic and the politics of the counterculture were profoundly influenced by the rising tide of interest in the East generated by the Vietnam War, the Cultural Revolution, and a disenchantment with the materialist, nine-to-five routine imposed upon them by the imperatives of mechanized labor and bureaucratic organization. Western counterculture appropriated the holistic and naturalist philosophy of the Chinese sages and folded it neatly into a justification for dropping out of the competitive rat race of an establishment culture that was conducting high-tech war against good, simple peasants working close to the earth in harmony with nature, each other, and the folk wisdom of their ancient traditions. One can still find the remnants of this generational phenomenon in the thousands of grayhaired, tie-dyed, European and American backpackers roaming aimlessly through the more remote regions of Asia.

Area studies approaches to China have a common origin in the attraction to an otherness defined by the modern, Western, present. The classicist seeks to save China from the ravages of modernization while the revolutionary hopes to use China to transcend them. Mao's death and China's opening to the West encouraged those who see China as a problem to try to tutor Chinese in the ways of the modern world, but the cumulative effect of all three schools works to deny China that possibility. The academic knowledge stockpiled by the romantics and the revolutionaries is often fused together to prove that China still cannot become modern. Richard Baum's (1982) “Science and Culture in Contemporary China: The Roots of Retarded Modernization” expressed a social scientific consensus that emerged after China renounced Maoism's more radical features in 1978. 
The institutionalization of the ethos of modern scientific rationalism in China is significantly impeded by the contemporary persistence of a number of atavistic cultural traits that have survived the passing of China's traditional Confucian order. The strength and durability of these traits, we shall further argue, is a function of their high degree of stylistic consonance with the ideology and political ethos of Chinese communism.

Even the supposedly Westernized Chinese intellectual community, which some area studies experts counted on to carry the ancient Middle Kingdom into the modern world, is now, in the wake of the failed protests of the summer of 1989, deemed incapable of overcoming the oppressive cultural weight of China's long and continuous past. Fairbank, commenting on the demonstrations in a preface to a book on human rights in China, explains:

In their confrontation at Tiananmen, both the rulers and their civilservants-to-be in the universities followed traditional patterns of conduct. The students passively petitioned their rulers to address their problems and allow them to take part in politics. The rulers reasserted their mandate to monopolize the direction of China's progress and prevent at all costs her falling into the chaos of unplanned activity and disharmony. They were unable to face the fact that, as Eastern Europe has now shown us, modern government requires popular participation in policy making. Only the small intellectual elite had independent views of the potentialities of political reform, and they were deeply frustrated. The most insidious aspect of this frustration lay in the fact the intellectuals were inbibited partly by the lingering influence of China's old order in their own thinking. (1990: 35)

Although the ingredients of student protest and public demonstration in April and June of 1989 superficially resembled their counterparts in Eastern Europe, they were deeply rooted in China's unique political tradition. Down to the twentieth century, China's rulers shared with their civil servants the ideology of imperial Confucianism, which enjoined every student to study the classics, revere their ancestors and the emperor and obey his officials. The emperor himself studying these same classics performed the duties that would keep the system working and in balance. These duties included the summary execution of all traitors who opposed imperial orders. 
Baum and Fairbank neatly sum up the area studies argument that imprisons China in an oversimplified past, and which has propelled iconoclasm in China for over a century. Genuine modernization requires political change. Political change requires cultural change. Cultural change is virtually impossible in China because its culture lingers, insidiously, even in the minds of the vanguard intelligentsia that has mastered and applied Western science and technology. Chinese culture demands passivity, respect for ancestors, rote memorization of the classics, and blind obedience to the duties they entail, duties which authority enforces with terror. The Chinese cannot become individualists; therefore, they cannot become modern; therefore, all their superficial progress is unsatisfactory; and therefore, we must carry out a more thorough purge of their "atavistic cultural traits."

The unspoken assumption that gives force to this argument is that evolution toward a very specific cultural modernization is inevitable, and determined by universal historical forces whose denial is the cause of China's sorrows. A horribly oppressive set of cultural and political demands attends this view of human history. In the world view of Pye, Fairbank, and many other area studies experts there is the supposition of a historical process of social and political modernization that not only requires the virtual duplication of the institutional forms of the Western bureaucratic and technical governing apparatus, but that also requires Chinese people to adopt Western norms and behavior in their human relationships. This kind of modernization intrudes into the inner recesses of the individual Chinese minds, and demands change if they are not to be deemed "retarded" by members of the Western social scientific community and the political and economic institutions they support with research and policy recommendations. This belief in the myth of a cultural or moral modernization requires nothing less than the creation of a new Chinese personality and with it new forms of interpersonal behavior. The most powerful impediment to that new personality is supposedly a Confucian-Leninist government that promotes a "deceptive," "amoral," "sterile," and "fatalistic" culture (Pye 1982, 1991).

The appearance and widespread acceptance of such views confirms another of J. L. Metha's (1989) observations on the problem of intercultural understanding: that our prejudices and prejudgments necessarily form a critical part of our efforts at understanding. Peter Winch expressed 
a similar view of intercultural communication, arguing that "to study another way of life is necessarily to seek to extend our own-not simply to bring the other within the already existing boundaries of our own, because the point about the latter in their present form, is that they ex hypothesi exclude that other" (1964: 307-324). Alasdair MacIntyre argued that the individual confronting the difficulties of cross-cultural evaluation must test "the theses proposed to him or her by each competing tradition" and "become involved in the conversation between traditions, learning to use the idiom of each in order to describe and evaluate the other or others by means of it" (1988: 398). These views of intercultural learning are also shared by many of my colleagues in the field of study abroad. Unfortunately, their expertise, because it is generally grounded in experience rather than in academic research and teaching, is often marginalized in the predominantly faculty-driven processes surrounding curricular design for most U.S. study abroad programs in China.

The extraordinarily narrow horizon that determines the thinking of the area studies literature that forms the basis of many implicitly-held assumptions about what should be happening in contemporary China is what has been known since the 1950s as "modernization theory." Jurgen Habermas correctly pointed out that the advocates of this theory mistakenly dissociate it from its origins in the history of European thought and "stylize it into a spatio-temporally neutral model for processes of social development" (1991: 2). That disassociation from European culture "breaks the internal connections between modernity and the historical context of Western rationalism." It creates an illusion that makes it absolutely impossible for an observer to become genuinely involved in the conversation between traditions, or to seek a way of looking at things that incorporates the views of the other. Because it is misconceived as a culturally neutral and objective point of departure, modernization theory can do nothing but try to force the other within the already existing boundaries of its own world view. A universal theory of modernization is unable to "shed the arrogance that often marks the enterprise of understanding the other, where togetherness slides into an objectification of the other" (Metha 1989: 13). There is no give and take between the Western culture of modernization and the many other different culturally and historically constituted horizons it encountered in the historical course of cross-cultural contact. China has not forced the West to reexamine its own pre- 
conceptions, or to "become aware of its prejudices and their restrictive influence on its thinking," despite the best wishes of scholars like Needham, Creel, and Hucker. Modernization theory is, culturally speaking, dictatorial. In an undeniably multicultural world, it is a totalitarian menace to cultural diversity.

A wave of post-modernist theory swept through the social sciences in the last decade, along with a general recognition that ethnic and national identities are not as malleable as the historical-materialist theses of modernization theory expected. Dreams of global conversion have given way to more defensive strategies, like those outlined in Samuel Huntington's (1998) “The Clash of Civilizations and the Remaking of World Order." For those who remain committed to integration, "globalization" has replaced "modernization" as the buzzword used to describe the same economic and technological processes that continue to structure increasingly interdependent international and intercultural relations. Changes in vocabulary and lessening degrees of theoretical absolutism mask a fundamental consistency in the area studies world view. The gurus of globalization see the retention of emotional ties to religious, cultural, and ethnic identities as regressive tendencies characteristic of elements of national populations that are not participating in globalization or who have been adversely affected by it. The idea that economic, technological, and scientific processes can and will change cultural values retains a firm grip on the minds of many students and scholars, and continues to operate from a position of undisputed supremacy in the popular discourse on America's relationship with China. One need look no farther than the recent debate over permanent most-favored nation trading status to find volumes of congressional committee testimony by area studies experts enlisted to help supporters overcome the objections of critics concerned about China's human rights record. Without exception the proponents of the bill argued that "engagement" would eventually lead to a more humane and agreeable Chinese political culture. ${ }^{2}$

\section{Study Abroad and the Chinese Experience}

The overall effect on many study abroad students, especially at the undergraduate level, where they have limited information and even less personal experience, is the nurturing of a psychology of learning that is 
not conducive to effective intercultural communication. The logic of the area studies inquiry into culture traps students in a mode of learning where group identifications are emphasized, group boundaries are more clearly drawn, and individual people become objects of study that are perceived to have certain global characteristics associated with their group identification. Of considerable interest is the fading of these boundaries and identifications in proportion to the length of time students remain abroad, the strength of their language skills, and the amount of time they spend actually engaged with individuals from the host culture. Unfortunately, most of the American undergraduate students who come to China have relatively weak language skills. They also tend to spend most of their single semester in the country with fellow foreign students in expatriate ghettos. Some, like the journalist who spoke to my students, return to stay for extended periods. One of the great pleasures of spending close to a decade in China working with study abroad programs is the good fortune of being able to observe the maturation of students well beyond the single semester experience. While this observational evidence is also anecdotal, the sentiment expressed by the speaker, with pride as well as modesty, that five years had reduced his knowledge of China to the contents of a matchbook cover, is not unusual in students who establish meaningful relationships with Chinese individuals. Through regular interaction with increased numbers of people at ever-higher levels of fluency in the language, students encounter ever-greater numbers of exceptions to the generalizations about Chinese culture articulated in academic theories. The correlations some social scientists (Hofstede 1997) have made on abstract cultural qualities like "individualism" or "power-distance" scales begin to look like little more than random numbers in the face of intimate knowledge of the thoughts and feelings of actual human beings. Global interpretations of the behavior of others lose their explanatory power, and students begin looking for resolutions of relationship and communication problems in the idiosyncratic particulars of the lives of individuals rather than in gross generalizations about Chinese culture. Unlearning becomes progress, and the results are demonstrable on a daily basis, as they become more proficient participants in a foreign culture.

I believe educators need to rethink the efficacy of presenting some studies to undergraduates students-for example, those that suggest Americans are somehow more inclined to democracy than Chinese because 
American culture promotes "weak uncertainty avoidance," or that Chinese culture is more "collectivist" (Hofstede, 1997). While trained scholars are keenly aware of the tentative nature of social science in general, and the problems with its propositions about cultural differences in particular, young people in the throes of a cross-cultural experience can and do give great weight to the hypotheses they encounter in the literature. One of the saddest realities of the twentieth century was the adoption of similar kinds of cross-cultural reasoning by generations of young Chinese intellectuals, fascinated with the West, impressed and oppressed by its political, economic, and technological power, in whom it generated a cultural selfhatred that still poisons social and political dialogue in China. ${ }^{3}$ Early in the century they had taken things so far as to consider giving up the Chinese language for Esperanto so that they would not be burdened by the limitations of their cultural heritage that were unavoidably passed on by continuing to use their own language:

To put it bluntly, Chinese characters are primitive, geared towards shapes not sounds, inconvenient to recognize and to write. Their meanings are confused, grammatical usage imprecise, and they are unfit for contemporary academic discourse, having not a single noun to express new ideas and things. Nine bundred ninety-nine out of a thousand are but signs to record Confucian and Taoist fallacies. This kind of script definitely cannot be used in this new era (...) if we want to keep China alive, to make the Chinese people cultured and enlightened citizens of the twentieth century, we must exterminate the Confucian and Taoist teachings at the root; eliminating the Chinese characters that recorded the these fallacies is the ultimate solution. (Qian 1918: 3)

Even in our own time the culturally nihilistic rhetoric can be just as virulent:

I think we Chinese are a high quality race. But why, for several bundred years now, have we been unable to finally pull China out of its bitter difficulties? What's the reason? I have a rude but comprebensive answer for you: that is, Chinese traditional culture carries a congenital virus, infecting children and grandchildren with an illness that down to this day we cannot cure. (Bo 1987: 12)

Fang Lizhi, a prize-winning astrophysicist and the hero of the 
Chinese student demonstrations in the late 1980s, believed he had found a suitable therapy:

In order to become truly modernized we have to import the spirit of Western civilization into China. Chinese civilization has achieved many profound insights, but it ignores logic. For the sake of our development, we must adopt the Western spirit. (Barme and Minford 1988: 395-397)

Armed with that agenda, and a gigantic replica of the Statue of Liberty, Fang's young and idealistic followers took to the streets and precipitated the latest in a very long and bloody line of confrontations over China's fate in the modern world. The horrible outcome should remind all of us, and especially those of us who claim to know something about culture, that words and symbols closely tied to the formation of our identities can evoke deep-seated passions and fears. They need to be used with extraordinary care, especially around students who are just beginning to tackle the psychological challenges of finding their place in the world. Sensitive young Chinese men and women trying to make sense of their lives, their society, and themselves, do not need to hear, or read, the words of prestigious "scientists," whether Chinese or Western, telling them they live in a backward, bizarre, deceptive, stagnant, unscientific, illogical, feudal badness. Equally sensitive young American women and men would be better off not listening to the theories of prestigious "scientists" who lead them to believe that their culture is the model the rest of the world will inevitably follow, or, if it does not, that other cultures will be perpetual enemies of Western civilization.

In the Chinese case, and most likely in the case of other nonWestern, "developing," or "third world" nations, the area studies literature, when it addresses culture, tends towards forms and subjects of analysis that emphasize macro-level comparisons, conflicts, and changes induced by patterns of intercultural contact at a group level. If the pedagogical aim of study abroad is to facilitate intercultural communication, develop intercultural competence, and cultivate a cadre of skilled individuals who will, in their professional lives, work cooperatively towards resolutions of the complex challenges to peace, prosperity, and the environmental sustainability of the planet presented by the undeniably multicultural constitution of the human community, then area studies courses may 
not be advisable prerequisites for the entry-level training we provide through our undergraduate abroad programs. Perhaps the order of presentation should be reversed. Study abroad might be a healthy prerequisite for area studies. When done well it can help students view macro-level judgments about culture more objectively, and with the benefit of unprejudiced data they collect on their own while "in the field."

\section{Conclusion}

In my view, philosophy, art, theology, history, literature and the traditional core subjects of the liberal arts education, especially those that help students become more familiar with the rich inheritance of their own cultural tradition, make far better prerequisites for study abroad than area studies courses. Broad-based liberal arts preparation helps students to think about their individual identity, the meaning of life, their relationship with others and their larger place in the world. It also develops skills of self-expression. The long-standing emphasis on foreign language acquisition in the development of study abroad programs is equally important, and there is a desperate need for a quantum leap forward in foreign language teaching. Even so, I believe we can dramatically improve intercultural competence by teaching students to communicate better in their own language. At the moment of intercultural contact the parties involved need to know how to speak to each other, but they also have to have something to say.

Area studies can play a constructive role in preparing students for study abroad when it stays away from addressing questions of culture. Factual information about the geography, demographic trends, or economic and political machinery operating in another part of the world can be an asset in the effort to maximize the educational potential of a period of study abroad. Too often, however, area studies inquiries are concerned with comparisons, and with theoretical speculation on the reasons for differences between countries and peoples. For many undergraduate students the subjective and tentative products of inquiries into cultural differences often take on the appearance of objective and scientific facts that students then use to resolve intercultural problems. In the Chinese experience, the accumulation, dissemination, and application of area studies theories on cultural differences and their impact on the course of contact between 
China and the West raises questions about the efficacy of employing area studies knowledge in the service of intercultural education. Students, teachers, and study abroad professionals should address these questions carefully before recommending prerequisites and developing orientation programs for students preparing to study abroad in China.

\section{Notes}

1 Needham, whose voluminous series on Chinese Science and Civilization stands as one of the greatest academic achievements of the twentieth century, is quoted in an article called "Orientalism and Sinology" in which Leys (1985) challenges the critique of Western orientalism made by Edward Said (1975). Leys argues_-using the authoritative weight of Needham's words - that the study of this other, because it can just as easily inspire "the deepest love," does not necessarily conform to Said's accusations that the "notion of an other culture" leads to various forms of aggression against it. Bataille would argue, like Melanie Klein, the British psychoanalyst, that love and hate are two sides of the same coin which put a distance between the object and its lover/hater. Needham's love serves as a confirmation of the same phenomenon that inspires the hate Said claims to encounter in Anglo-American studies of the Middle East.

2 The part of this argument that has the most profound influence on study abroad students is that movies, songs, and popular American culture will somehow make Chinese people better human beings. Orville Schell (1988) describes with some regret but with a clear indication of approval the Western cultural fads (bikinis and muscle magazines) rushing to fill a void left by the collapse of Maoism, and argues that Chinese are becoming more "inward-looking" and less concerned about public life, more interested in private concerns. Discos would lead to democracy. The bureaucratic consumer culture of the modern West, lamentable as some aspects of it may be, is creating a new Chinese youth who are, for the first time, more interested in themselves as individuals.

3 Joseph R. Levenson (1968) bases his entire analysis of the early twentieth century on the assumption that "Man is not a neutral machine calmly recording right answers; if a foreign answer is to be intellectually accepted as right, the native culture's emotional claims must somehow be 
squared." The attempt to square these claims is, for Levenson, a principle which "makes the chronological sequence in modern Chinese history logically comprehensible." Michael Gasster (1987) claims that "The earliest, most widespread, abiding, and angry complaint that the Chinese revolutionaries had was that China's position in the world was humiliating," and that the intellectual history of the period surrounding the collapse of the imperial order could be "linked to a series of Sputnik scares" that had effects which produced "psychological disorientation." Arif Dirlik (1989) argued that the "experiences of the May Fourth Radicals" is characterized by "a sense of crisis" and "an alienating social environment" that left them in a state of profound confusion and frustration and drove them to pursue "self-realization through experimentation," which often found its "ultimate expression in self-negating political organization or descent into social hedonism."

\section{References}

Barme, Geremie, and Minford, John, Eds. Seeds of Fire: Chinese Voices of Conscience. New York: Hill and Wang, 1988.

Baum, R. "Science and Culture in Contemporary China: The Roots of Retarded Modernization." Asian Survey 22.12: 1167-1189. 1982.

Bo, Yang. Choulou de Zhongguoren. Beijing: Beijing Waiwen Chubanshi. 1987.

Creel, Herrlee. Chinese Thought from Confucius to Mao Tse-tung. Chicago: University of Chicago Press. 1953.

Dirlik, Arif. The Origins of Chinese Communism. New York: Oxford University Press. 1989.

Fairbank, John King et. al. Children of the Dragon: Human Rights in China. New York: HRIC Inc. 1990.

Fairbank, John King et. al. The Great Chinese Revolution. New York: Harper \& Row. 1987.

Gasster, Michael. Chinese Intellectuals in Crisis: Search for Order and Meaning 1890-1911. Berkeley: University of California Press. 1987.

Habermas, Jurgen. The Philosophical Discourse of Modernity: Twelve Lectures. Cambridge: MIT Press. 1991.

Hinton, William. Turning Point in China: An Essay on the Cultural Revolution. New York: Monthly Review Press. 1972.

Hofstede, Geert. Cultures \& Organizations: Software of the Mind, Intercultural 
Cooperation and its Importance for Survival. New York: McGraw Hill. 1997.

Hsu, Francis. Americans and Chinese: Reflections on Two Cultures and Their People. New York: Doubleday, American Museum Science Books. 1972.

Hucker, Charles O. China to 1850: A Short History. Stanford: Stanford University Press. 1978.

Huntington, Samuel. The Clash of Civilizations and the Remaking of World Order. New York: Touchstone Books. 1998.

Levenson, Joseph R. Confucian China and Its Modern Fate: A Trilogy. Berkeley: University of California Press. 1968.

Leys, Simon. The Burning Forest: Essays on Culture and Politics in Contemporary China. London: Paladin. 1985.

MacIntyre, Alasdair. Whose Justice? Which Rationality? Notre Dame: University of Notre Dame Press. 1988.

Metha, J.L. "Problems of Understanding." Philosophy East E West. 39.1: 115. 1989.

Needham, Joseph. Science and Civilization in China Vol. I. Cambridge: Harvard University Press. 1954.

Pye, Lucian W. "Political Science and the Crisis of Authoritarianism." American Political Science Association Review. 84.1: 3-19. 1990.

Pye, Lucian W. "China: Erratic State, Frustrated Society." Foreign Affairs. 20.12: 54-74. 1991.

Pye, Lucian W. "Nuances in Chinese Political Culture." Asian Survey. 22.12: 1147-1165. 1982.

Pye, Lucian W. The Spirit of Chinese Politics. Cambridge: MIT Press. 1968. Qian, Xuantong. New Youth. Zhongguo Xiandaisixiangshi Ziliaojianbian Di Er Juan. Hangzhou: Zhejiang Renmin Chubanshi. 1918.

Said, Edward. Orientalism. New York: Vintage Books. 1979.

Schell, Orville. Discos E Democracy: China in the Throes of Reform. New York: Anchor Books. 1988.

Selden, Mark. The Yenan Way in Revolutionary China. Cambridge: Harvard University Press. 1971.

Schurman, Franz and Schell, Orville Eds. The China Reader: Communist China, Revolutionary Reconstruction and International Confrontation, 1949- Present. New York: Vintage Books. 1967.

Spence, Johnathan. The Search for Modern China. New York: W.W. Norton 
Frontiers: The Interdisciplinary Journal of Study Abroad

\& Company. 1990.

Terrill, Ross Ed. The China Difference. New York: Harper \& Row. 1979.

Watts, William. Americans Look at Asia: A Potomac Associates Policy Perspective. Cambridge: Opinion Dynamic Corporation. 1999.

Winch, Peter. "Understanding A Primitive Society." American Philosophical Quarterly. 1: 307-324. 1964.

Wilson, Dick. Anatomy of China: An Introduction to One-Quarter of Mankind. New York: Weybright and Talley. 1968. 